\title{
Corporate Governance and the Credibility of Financial Statements in Nigeria
}

\author{
Eyesan Leslie Dabor \\ University of Benin, Nigeria \\ Semiu Babatunde Adeyemi \\ University of Lagos, Nigeria
}

\begin{abstract}
Optimal decision-making is based on the quality of information available to the decision maker. Financial statements published by companies are the major sources of financial information available to investors and other stakeholders of the company. The credibility of these financial statements has very salient implications for the quality of decisions that investors can make. By using primary data collected from two hundred and forty eight respondents, and secondary data from twenty quoted companies in Nigeria, we sought to determine the relationship between corporate governance and the credibility of financial statements. The secondary data was analysed using multiple regression, while the primary data was used to test hypotheses using the chi-squared test. We find that including non-executive directors on the board, and compliance with audit committee composition as provided by the Nigerian Companies and Allied Matters Act (CAMA) 1990 are likely to enhance the credibility of financial statements. We did not find evidence to suggest that CEO duality or absence of institutional shareholding would have negative effect on the credibility of financial statements. We recommend that apart from including non-executive directors on the board and ensuring that the composition of the audit committee complies with corporate regulatory framework, stakeholder must constantly assess the credibility of the financial statements by assessing the benefits accruing to them in relation to their financial exposure to the organization.
\end{abstract}

\section{Keywords}

Corporate governance, CEO-duality, discretionary accrual, audit committee, credibility.

\section{Background to the Study}

The quality of decisions that investors can make is largely dependent on the quality of information available to them. This information can be classified into quantitative (financial) and qualitative (non financial). However, financial information is of great significance, as it requires a reasonable level of skill to interpret and use. The published financial statements prepared by directors of limited liability companies and audited by external auditors remain the primary means of informing shareholders and other users about the financial performance, progress and position of the business. Ceteris paribus, audited financial statements should be credible, believable and reliable. However, this condition, other

Copyright (C) 2009 Victoria University. This document has been published as part of the Journal of Business Systems, Governance and Ethics in both online and print formats. Educational and non-profit institutions are granted a nonexclusive licence to utilise this document in whole or in part for personal or classroom use without fee, provided that correct attribution and citation are made and this copyright statement is reproduced. Any other usage is prohibited without the express permission of the things being equal, may not hold. Exceptions to this assumption include: insufficient corporate governance structures, codes and institutions, timeliness of the financial information and the level of skill and the sophistication of the capital and financial markets for which the financial statements have been prepared. Low quality reporting results from sloppy accounting, inadequate regulation, crony capitalism, lagging and 
multiple regulations, economic and political factors influencing managers' and auditors' incentives (see Liu and Zhang, 1996; Ball, et al., 2003; Fox, 1998; and Rask, et al., 1998).

When there is a separation of ownership from control of a business enterprise, as in the limited liability company, there is usually a tendency for managers of these companies to engage in fraudulent financial reporting to protect their interest at the detriment of the interests of users of financial statements. Oyejide and Soyibo (2001) observed that managers in some unforeseen circumstances assume contingent control rights that provide them with the potentials to operate against investors' best interest and as such conceal some pieces of information in order to align the interest of managers to that of the stakeholders. In order to revitalize the confidence of reporting system, there has been a clamour for corporate governance. Sloan (2002) is of the view that the credibility of financial statements depends largely on the existence of strong corporate governance structures. The Central Bank of Nigeria Code of Corporate Governance for Banks (2006) states: "specifically for financial sector, poor corporate governance was identified as one of the major factors in virtually all known instances of financial institution distress in the country." Kumolu (2007) points out that the thrust of corporate governance lies in putting in place structures that would ensure that management is accountable to the stakeholders.

The review of literature shows an inextricable link between corporate governance and board effectiveness. It is only an effective board that would be concerned about the credibility of financial statements. An effective board is one that seeks to maximize shareholders' wealth through the means of enterprise and accountability. It is this accountability dimension of an effective board that links corporate governance with the credibility of financial statements.

Accounting is big business because trust is a scare commodity. The accountant and indeed the auditor are in business because they are believed to produce believable financial reports. In a corporate setting, it is the duty of directors to prepare financial statements to disclose their stewardship to shareholders. Directors usually employ both accountants and auditors. The employment of the auditors by the directors is subject to ratification by the shareholders. When directors have fraudulent motives both the accounting and auditing functions are paralyzed. Consequently, in order to check the fraudulent intentions of directors, a strong corporate governance mechanism is required.

In this study we examine the relationship between corporate governance and the credibility of financial statements. The study contributes to literature by using Nigeria data to examine this issue. Moreover, the study uses both primary and secondary data. Specifically the study attempts to find answers to the following questions:

i. Does CEO duality enhance the credibility of financial reports?

ii. How effective is the audit committee in ensuring the credibility of financial statements?

iii. In what ways do the variables like board size, board structure and shareholding structure affect the credibility of financial statement?

The current study is aimed at finding out the relationship between corporate governance and credulity of financial statements. Weak corporate governance structures provide incentives to management to manipulate financial statements, and this results in low reporting quality. However, the exact relationship between corporate governance variables and quality of financial reports is not exactly known because the literature is unresolved on the issues of board size, board structure board independence, ownership structure and CEO duality as they affect the quality of corporate governance. Basically, as it relates to financial reporting the main objective of corporate governance is to ensure that the financial statements prepared by directors and attested to by independent auditors are actually true and fair. We test in this study one dimension of credibility, which is the absence of earnings manipulation through discretionary accruals. Specifically the study seeks to find out:

i. whether the absence of CEO duality mars credibility of financial statements;

ii. whether the presence of more non-executive directors relative to executive directors enhances the credibility of financial statements; 
iii. whether audit committee constituted in accordance with the extant corporate regulatory pronouncements in Nigeria [e.g., s.359(4) of the Companies and Allied Matters Act, (CAMA) 1990] promotes the credibility of financial statements in the country; and

iv. whether institutional ownership of shares enhances the credibility of financial statements.

The following hypotheses are formulated to guide in finding answers to the research questions:

$\mathrm{H}_{1}$ : Companies having $\mathrm{CEO}$ duality do not produce more credible financial statements than those that do not have CEO duality.

$\mathrm{H}_{2}$ : Companies having boards dominated by non-executive directors do not have more credible financial statements than those whose boards are dominated by executive directors.

$\mathrm{H}_{3}$ : Companies having audit committees constituted as stipulated by CAMA 1990 produce less credible financial statements than those that have audit committees constituted without regard to the provisions of CAMA.

$\mathrm{H}_{4}$ : Companies with institutional shareholders produce less credible financial statements than those without institutional shareholders.

In this study, we examine the relationship between corporate governance and the credibility of financial statements, using both primary and secondary data. We capture credibility of financial statements by using absolute discretionary accrual. The corporate governance variables used include proportion of non-executive directors, institutional shareholding, role of Chief Executive Officers (CEOs) and audit committee composition.

Section II reviews the literature. The research design, model specifications, the data used in the analysis, and sample selection procedure are contained in Section III. Section IV captures the data analysis and research findings while Section V summarises and concludes the paper.

\section{Review of the Literature}

The Wikipedia online encyclopaedia (2006) sees corporate governance as framework of rules, relationships, systems and processes within and by which fiduciary authority is exercised and controlled in corporations. These rules include applicable laws of the land and the internal rules of the company. Relationships include those between related parties, managers, directors of board, regulatory authorities, employees and the community at large. Systems and processes deal with matters such as delegation of authority, performance measurement, assurance mechanism, reporting requirements and accountabilities. Hence, corporate governance structures spell out the rules and procedures for making decisions on corporate affairs. It provides the structure through which company objectives are met, as well as a means for monitoring the attainment of the objectives.

Corporate Governance can be viewed from a narrow or broad perspective. From a narrow perspective, corporate governance is concerned with structures within which a corporate entity or enterprise receives its basic orientation and direction (Rwegasira, 2000), and from a broad perspective, corporate governance may be seen as the heart of both a market economy and of a democratic society (Sullivan, 2000).

The literature on corporate governance is awesome, veering into economics, law, business, finance and accounting. The focus of much effort in corporate governance research is to try to establish whether there is any relationship between corporate governance variables and some other variables such as earnings management, corporate failure, and corporate performance.

Board of Directors: The board of directors is the central link between corporate governance and performance of management. Jensen (1993) contends that while the ostensible role of the board of directors (BOD) is to provide high-level counsel and oversight to management, corporate internal control problems often originate from the BOD itself. He attributes the BOD's governance features to factors such as CEOs' agenda - setting power, low equity ownership of the board members, 
overcrowding of the board and a board culture that encourages consent rather than dissent. Given this scenario, the credibility of financial statements may be questionable. Size, independence and share ownership of the board are the most often discussed issues in the literature when talking about the attributes of the board.

An independent board is one that is free from manipulation and control of the CEO. Fama and Jensen (1983) argue that including outside directors (also referred to as non-executive or independent directors) enhances the viability of the board and reduces the probability of top management colluding to expropriate shareholders' wealth. However, there is no general consensus as to the perceived benefit of outside directors. Crystal (1991) for example contends that the CEO essentially hires outside directors, hence they are unlikely to assume a decisive position to the CEO. Byrd and Hickman (1992) noted that a clever CEO may have more outside directors to give shareholders a false impression of having a high quality of governance system when, in reality, they are panders for the achievement of narrow and suboptimal objectives.

Empirically, research remains inconclusive on the degree of effectiveness of board and the inclusion of outside directors. Particularly, Bedard, et al. (2001) considered four variables in relation to corporate boards: board independence, the inclusion of independent directors on the board, the separation the office of the CEO from that of the chairman of the board, and the presence of an independent nomination committee. They find that independent directors are considered better monitors than other directors because they have the ability to act in the best interest of the company. They also report that non-executive directors have incentives to develop a reputation as experts in decision control and monitoring.

There is no consensus in the literature as regards the relationship between the size of the board and board effectiveness. The size of the board is defined as the total number of directors (both executive and non-executive) on the board. Dalton, et al. (1999) reported that large boards motivate better environmental links and more expertise. However, Jensen (1993), Eisenberg, et al. (1998) and Yermack (1996) find that an "over crowded" board is likely to be an ineffective board. What is "overcrowded" is definitely relative.

It is believed that a director with a sizeable ownership in the firm is more likely to question and challenge management proposal because his or her interest is at stake (Mace, 1986). Jensen (1993) argues that encouraging outside directors to hold a substantial ownership position in the firm provides them with better incentive to monitor management closely and this suggests that credibility is positively related to outside directors' ownership.

Morck, Shleifer and Vishny (1988) observe that there are two opposing effects of inside ownership - the alignment and the managerial entrenchment effects. Managerial interests become more closely aligned with shareholder interests as inside stock ownership rise from zero. However, managerial entrenchment effect sets in where management's stock ownership becomes large enough to give managers control.

A situation where the CEO holds the position of the chairman of the board has been described as a prescription for failure of internal control system (Jensen, 1993 and Fama and Jensen, 1983). However, Brickely, et al. (2000) suggest that the separation of these two positions (CEO duality) engenders monitoring costs, which may offset the benefits of separation of the roles of CEO and board chairman.

\section{Research Design}

We use both primary and secondary data in this study. The primary data is collected using a purposelyconstructed questionnaire. The questionnaire is distributed to users of financial statement of companies who are knowledgeable in financial reporting and analysis. Knowledge ability is determined by asking the respondent whether he or she is knowledgeable enough to interpret financial statement information for economic decision-making purposes. Two hundred and forty-eight copies of the questionnaire were given to those users perceived as being knowledgeable by the researchers, and who were ascertained to understand the basic issues in financial reporting. Academic qualification, the kind of work the 
respondents do, together with their disciplines helped to determine "knowledge ability". The analysis of the data supplied through the questionnaire was done using descriptive and inferential statistics. The secondary data were gathered from the annual reports of 20 randomly selected quoted and active Nigerian Stock Exchange companies.

Model Specification: The model first establishes total accruals, which were then partitioned into discretionary (managed) and non-discretionary accruals. The discretionary portion is then regressed on corporate governance variables of sampled companies.

Chen et al. (2007) opines that accruals are likely to capture evidence of financial misreporting because they reflect manager's accounting estimates and accounting choices. Thus, discretionary accruals is used to proxy the credibility of financial statements. In establishing discretionary accruals, we used the modified Jones model. Kothari, et al. (2005) and Dechow, et al. (1995) have identified the Jones model as a strong tool for measuring discretionary accruals. The model uses such components of financial statements as turnover (sales revenue), account receivables, profit and assets to establish discretionary accruals.

Firstly, the model establishes total accruals by subtracting cash flow from operations from net income before extraordinary items. Thus,

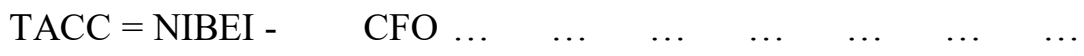

Where TACC represents total accruals, NIBEI is the net income before extraordinary items, and CFO is cash flow from operations.

Total accruals are then partitioned into two components, i.e., non-discretionary accruals, which relate to normal activities of the company and discretionary accruals, which are determined according to the subjective reasoning of management. That is, discretionary accrual is a function of management choice of accounting policies.

$$
\mathrm{TACC}=\mathrm{a}_{0}+\mathrm{a}_{1}(\triangle \mathrm{REV}-\triangle \mathrm{REC})+\mathrm{a}_{2} \text { PPE }+\mathrm{a}_{3} \operatorname{ROAM}_{\mathrm{t}-1}+\mathrm{e} \quad \ldots
$$

Where $\triangle \mathrm{REV}$ is change in revenue; $\triangle \mathrm{REC}$ is change in accounts receivable; PPE means plants, property and equipment (fixed assets) and ROAM is return on assets managed in the previous accounting period. All the variables that enter the equation are scaled by total assets (TA) of the previous year - TA $_{t-1}$

The non-discretionary accruals portion (NDA) is also modelled as a function of the change in revenue, change in accounts receivable, plant, property and equipment and return on assets managed in the previous accounting period as follows:

$$
\text { NDA }=\mathrm{a}_{0}+\mathrm{a}_{1}(\triangle \mathrm{REV}-\triangle \mathrm{REC})+\mathrm{a}_{1} \mathrm{PPE}+\mathrm{a}_{3} \operatorname{ROAM}_{\mathrm{t}-1} \quad \ldots \quad \ldots \quad \ldots
$$

The difference between (2) and (3) above is the residual e, and this is the discretionary accruals (DA). Thus,

$$
\left.\mathrm{DA}=\mathrm{TACC}-\left[\mathrm{a}_{0}+\mathrm{a}_{1}(\triangle \mathrm{REV}-\triangle \mathrm{REC})+\mathrm{a}_{2} \mathrm{PPE}+\mathrm{a}_{3} \operatorname{ROAM}_{\mathrm{t}-1}\right)\right] \ldots \quad \ldots
$$

The model parameters to be estimated are $\mathrm{a}_{0}, \mathrm{a}_{1}, \mathrm{a}_{2}$, and $\mathrm{a}_{3}$.

All the variables, except $\mathrm{ROAM}_{\mathrm{t}-1,1}$ are scaled by total assets in previous year.

Chen, et al. (2007) provide justification for the inclusion of the variables by pointing out that normal levels of working capital accruals (non-discretionary accruals) are controlled by changes in revenue (turnover) less changes in receivable $(\triangle \mathrm{REV}-\triangle \mathrm{REC})$, while normal levels of depreciation charges and deferred tax accruals are controlled through property, plant and equipment (PPE). The inclusion of return on assets managed in previous year was added as suggested by Kothari, et al., (2005).

Having obtained discretionary accruals as above, the multivariate regression model using the ordinary least square estimation method as suggested by Oaikhenan and Udegbunam (2004) below is used to 
expound the relationship between corporate governance and credibility of financial statements as follows:

$$
\begin{aligned}
& \mathrm{ADA}=\mathrm{a}_{0}+\mathrm{a}_{1} \mathrm{CEO}+\mathrm{a}_{2} \text { PNED }+\mathrm{a}_{3} \mathrm{AUDCOM} \\
& +\mathrm{a}_{4} \text { INST }+\mathrm{a}_{5} \text { SIZE }+\mathrm{a}_{6} \text { ROAM } \\
& +\mathrm{a}_{7} \operatorname{LEV}+\mathrm{a}_{8} \operatorname{LOSS}+\mathrm{a}_{9} \operatorname{AUD}+\varepsilon \ldots \ldots \quad \ldots \\
& \text { where } \mathrm{ADA}=\text { Absolute discretionary accrual } \\
& \mathrm{CEO}=\text { Role of Chief Executive Officer }
\end{aligned}
$$

\begin{tabular}{|c|c|c|}
\hline INST & $=$ & $\%$ of institutional shareholding exceeding $5 \%$. \\
\hline SIZE & $=$ & Measured by the log of sales revenue \\
\hline ROAM & $=$ & Ratio of net income before interest and taxes to total assets \\
\hline LEV & $=$ & Ratio of total debts to total assets. \\
\hline LOSS & $=$ & Coded 1 if company experienced a net loss and 0 if otherwise \\
\hline AUD & $=$ & Auditors report, coded 1 if not qualified and 0 if qualified: \\
\hline
\end{tabular}

Director (coded 1 if different from chairman and coded 0 if otherwise)

$$
\begin{array}{lll}
\text { PNED } & = & \text { Proportion of Non-executive Director } \\
\text { AUDCOM }= & \text { Audit committee composition, coded } 1
\end{array}
$$

if complied with CAMA, 1999, 0 if otherwise

The model parameters would be estimated using the ordinary least square method. The dependent or explained variable in the model is absolute discretionary accruals (ADA), which is the proxy for the credibility of financial reporting. The explanatory variables comprise the research variables and dummy variables.

The research variables are corporate governance mechanisms measured by the role of the chief executive director or officer (CEO), proportion of non-executive directors (PNED), audit committee composition (AUDCOM) as stipulated by CAMA, 1990, and institutional shareholding (INST). The $a$ priori expectation is that these corporate governance variables are negatively related to absolute discretionary accruals.

The control variables include size measured by the logarithm of sales revenue or turnover. Large companies may have less incentive to indulge in fraudulent financial reporting, but increase in sales could mean increase in receivables. Returns on assets managed (ROAM) are added as control variable for firm profitability and indicate the efficiency in the utilization of resources. Leverage is added because corporations approaching debt covenant violation may undertake income increasing or decreasing steps. Loss is added as corporations in financial distress may also increase reported income to reduce losses. Finally, auditors' report is included where financial reports are qualified, indicating possibility of misreporting.

\section{Data Analysis}

The descriptive statistics in Table 1 were computed based on the data presented in Appendix 2. The Table shows research and control variables. CEO with a sample size of 19, has a mean and standard deviation of 1.0000 and 0.0000 respectively. Similarly, PNED has its sample size as 16 with mean (standard deviation) as 0.7349 (0.0174). The mean and standard deviation of other variables are SIZE, 0.8456 (0.3546); ROAM, 0.1472 (0.0112); LEV, 0.5823 (0.0245); LOSS, 0.15 (0.0361) and AUD, 9474 (0.0474) respectively. 
Table 1 Descriptive Statistics for Explanatory Variables

\begin{tabular}{|l|l|l|l|l|l|l|}
\hline Variable & $\mathrm{N}$ & Mean & Std. Dev. & Mini & Maxi & Range \\
\hline CEO & 19 & 1.0000 & 0.0000 & 0.0000 & 1.0000 & 1.0000 \\
\hline PNED & 16 & 0.7349 & 0.0174 & 0.5556 & 0.9091 & 0.3535 \\
\hline AUDCOM & 20 & 0.9500 & 0.0475 & 0.0000 & 1.0000 & 1.0000 \\
\hline INST & 18 & 0.5614 & 0.0430 & 0.1126 & 0.8844 & 0.7718 \\
\hline SIZE & 20 & 0.8456 & 0.3546 & 5.6262 & 7.9044 & 2.2782 \\
\hline ROAM & 20 & 0.1472 & 0.0112 & 0.0049 & 0.4686 & 0.4637 \\
\hline LEV & 20 & 0.5823 & 0.0245 & 0.3440 & 0.8961 & 0.5521 \\
\hline LOSS & 20 & 0.1500 & 0.0361 & 0.0000 & 1.0000 & 1.0000 \\
\hline AUD & 19 & 0.9474 & 0.0474 & 0.0000 & 1.0000 & 1.0000 \\
\hline
\end{tabular}

Source: Computed from Annual Reports

A further analysis of the data in Appendix 2, shows that 19 companies in the sample had separate roles for their chief executive officer and board chairman. The information in financial report of one company regarding CEO duality could not be ascertained and so it was left out. Similarly, 16 of the 20 companies had their proportion of non-executive directors greater than their executive directors; the remaining 4 companies had either equal presentation or less proportion of non-executive directors to executive directors. Eighteen companies had institutional shareholders with more than 5\% holding while only 2 companies had no institutional shareholder. Lastly, while 19 companies had their auditor's report on their financial statements, no record was found for auditor's report of one company. Of the 19 companies whose records were found, only one has a qualified report.

OLS Regression Result: There were 208 companies quoted on the Nigerian Stock Exchange as at $1^{\text {st }}$ January, 2007, however, after exclusions, the population of our interest reduced to 127. It is from this 127 that 20 companies were selected. Appendix 1 shows the variables for the estimation of discretionary accruals, while Appendix 2 shows the control and research variables for data analysis. The final result is summarised below (The $t$ values are shown below the relevant parameters in parentheses):

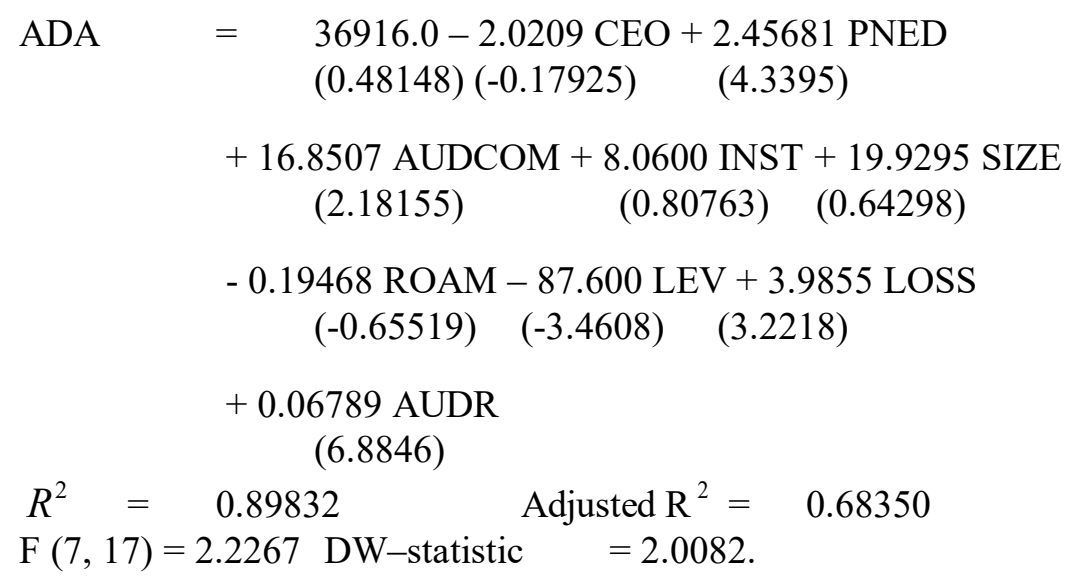

The $R^{2}$ of 0.89832 implies that about $90 \%$ variation in ADA is explained by the independent variables, namely, CEO, PNED, AUDCOM, INST, SIZE, ROAM, LEV, LOSS and AUDR. The adjusted $\mathrm{R}^{2}$ of $68 \%$ shows that the model is a good fit with high predictive power. The $F$-statistic, which measures existence of linear relationship between the dependent variables, reveals a significant statistical relationship as the $F_{\text {calc }}$ of 2.2267 is greater than $F_{\text {tab }}$ of 2.10 at $10 \%$ level of significance. Our a priori expectation is that CEO, PNED, AUDCOM and INST were all negative. This is not empirically supported as only CEO was negatively related to ADA. Specifically, however, the negative relationship is not strong as the absolute t-value of CEO is 0.17925 , which is less than the $t_{\text {tab }}$ value of 1.734 at $5 \%$ level of significance.

PNED showed a positive relationship with the dependent variable, ADA. This relationship is significant as $t$-ratio value of 4.3395 is greater than the $t$-tabulated value of 1.734 at $5 \%$ level of significance. 
Audit committee composition (AUDCOM) measured by the use of a dummy variable coded 1 if complied with the requirement of the company's act was also positively related to ADA in a significant manner as the $t$-ratio value of 2.18815 is greater than $t_{t a b}$ value of 1.734 at $5 \%$ level of significance. The fourth research variable INST shows a positive insignificant relationship with ADA, as the t-ratio value of 0.80763 is less than the $t_{t a b}$ value of 1.734 at $5 \%$ level of significance.

There is a negative relationship between the control variables ROAM and LEV, and the dependent variable ADA. However, the relationship for both is insignificant as shown by their t-ratio values of 0.65519 and -3.4608 at $5 \%$ level of significance. However, SIZE, LOSS and AUD all showed positive relationship with ADA. However SIZE is insignificant while the others are significant at $5 \%$ level of significance as shown by their t-ratio values.

The data from the responses to the research questionnaire were analysed and reported next.

Table 2 Audit Committee and Credibility Financial Reports.

\begin{tabular}{|lcc|}
\hline Responses & No of Respondents & (\%) Respondents \\
Yes & 160 & 65 \\
No & 88 & 35 \\
Total & $\mathbf{2 4 8}$ & $\mathbf{1 0 0}$ \\
\hline
\end{tabular}

Two hundred and forty-eight copies of the questionnaire were distributed to the respondents who were considered to be knowledgeable and $65 \%$ of these respondents $(160)$ believed that the presence of audit committee improves the credibility of financial statements while the remaining 88 respondents (or 35\% of the total respondents) held a contrary view. We use the results in Table 2 to test hypothesis III which proposes that companies having audit committees as stipulated by CAMA, 1990 do not produce credible financial statements.

The result shows that $\chi_{\text {calc }}^{2}=7.80>\chi_{\text {tab }}^{2}=3.84$, we reject null hypothesis and retain alternative hypothesis that companies having audit committee as stipulated by CAMA 1990 produce credible financial statements.

Table 3 CEO duality and credibility of financial statement

\begin{tabular}{|lcc|}
\hline Responses & No. of Respondents & \% Respondents \\
Yes & 200 & 81 \\
No & 48 & 19 \\
Total & $\mathbf{2 4 8}$ & $\mathbf{1 0 0}$ \\
\hline
\end{tabular}

Source: Field study, 2008

Two hundred respondents of the 248 respondents think that CEO duality reduces the credibility of financial statements. This represents $81 \%$ of total respondents. These data were used to test hypothesis I that states that companies with different persons for the office of CEO and chairman do not produce credible financial reports.

Since $\chi_{c a l}^{2}=28.4>\chi_{\text {tab }}^{2} 3.84$ we reject the null hypothesis and retain the alternative hypothesis. We conclude that companies with different persons for the office of CEO and chairman produce credible report. 
Table 4: Institutional Shareholders and Credibility of Financial statements

\begin{tabular}{|ccc|}
\hline Responses & No of Respondents & \% Respondent \\
Yes & 161 & 65 \\
No & 87 & 35 \\
Total & $\mathbf{2 4 8}$ & $\mathbf{1 0 0}$ \\
\hline
\end{tabular}

Source: Field study, 2008

Sixty-five per cent or 161 respondents were of the opinion that the presence of institutional shareholders would enhance the credibility of financial statements. We use this result to test hypothesis IV: "There is no significant difference in the opinions of respondents who agreed that corporations with institutional shareholders do not produce credible financial statements and those who disagreed." Since $\chi_{\text {cal }}^{2}=2.00<$ $\chi_{\text {tab }}^{2}=3.84$, we retain the null hypothesis.

Table 5: Proportion of non-executive directors and credibility of financial statements

\begin{tabular}{|lcc|}
\hline Responses & No of Respondents & \% Respondent \\
Yes & 100 & 40 \\
No & 148 & 60 \\
Total & $\mathbf{2 4 8}$ & $\mathbf{1 0 0}$ \\
\hline
\end{tabular}

Source: field study, 2008

One hundred or $40 \%$ of the respondents were of the view that including non-executive director enhances credibility of financial statements while the other $60 \%$ or 148 of the respondents did not think so. Generally, the respondents were of the view that not including non-executive directors on the board of companies operating in Nigeria will not affect the credibility of financial statements in the country as currently observed. The extent of the statistical difference in the two opinions held was tested using $\chi^{2}$. Since $\chi_{\text {cal }}^{2}=2.32<\chi_{\text {tab }}^{2}=3.84$, we retain the null hypothesis and reject the alternative hypothesis. Hence, we conclude that the inclusion of non-executive directors do not enhance credibility of financial statements.

\section{Summary, Conclusions and Recommendations}

Summary of Findings: Credibility in financial reporting is a crucial factor in assessing the performance of every corporate organization in relation to acceptable level of corporate governance practice. This paper has executed a survey-based research design along with multiple-regression approach to uncover the extent to which corporate governance structures determine the credibility of financial statements in Nigeria. The primary data and secondary data collected and analysed revealed that:

i. where the office of the CEO is separated from that of the chairman, that is absence of CEO duality, the financial statements produced appeared to be credible;

ii. companies having audit committee as stipulated by CAMA, 1990 seem to produce credible financial statements;

iii. companies with institutional shareholders did not appear to produce credible financial reports; and

iv. there was no evidence to suggest that the inclusion of non-executive directors would enhance credibility of financial statements prepared by quoted companies in Nigeria.

The analysis of the secondary data using multiple regression, uncovered the following:

i. there is a weak negative relationship between the policy of separating the office of the chairman and CEO, and the credibility of financial statements;

ii. there is a strong positive relationship between proportion of non-executive directors, and the credibility of financial statements; 
iii. audit committee composition was found to be significantly and positively related to the credibility of the financial statements; and

iv. companies having institutional shareholder did not appear to have an edge over those without institutional shareholders in the generation of credible financial statements.

Conclusion and Recommendations: Credibility of financial statements is a crucial variable in determining investor choices and decisions. Strong corporate governance structure would enhance the credibility of these statements. Our findings generally corroborate this. To strengthen corporate governance is to ensure corporate democracy by ensuring a power balance among stakeholders of the firms namely shareholders, directors, management and other stakeholders. The literature is not settled on the exact relationship between corporate governance structure and firm performance. As the debate rages, the ultimate decision as to the appropriate corporate governance mechanism mixed that would enhance credibility of financial statements, stakeholder must have an unwavering gaze at performance (quantitative and qualitative), both monetary and non-monetary, and both accounting and nonaccounting measures. At the end of the day it is not just good corporate governance or credible financial statement that stakeholders are interested in, but rather in a company whose performance can be quantified in terms of improved and improving benefits for the stakeholders.

\section{References}

Ball, R., Robin, A. and J. S. Wu (2003). "Incentives versus Standards: Properties of Accounting Income in Four East Asian Countries". Journal of Accounting and Economics, 36, 235-270.

Brickley, J. A., R.C. Lease, and C. Smith, Jr. (2000). "Ownership Structure and Voting on Antitakeover Amendments." Journal of Financial Economics, 20,267-291.

Bryd, J. W. and A. Hickman (1992). "Do outside Directors Monitor Managers? Evidence from Tender Offer Bids." Journal of Financial Economics, 19 (October), 195-222.

Chen, K.Y., Elder, R.J. and Hsieh, Y. (2007). "Corporate Governance and Earnings Management: The Implication of Corporate Governance Best Practice Principles for Taiwanese Listed Companies", Working Paper Series (downloaded from www.ssrn.com).

Chtourou, S. M., J. Bedard and L. Courteau (2001). "Corporate Governance and Earnings Management", Working Paper Series (downloaded from www.ssrn.com).

Crystal, G. S. (1991). In search of Excess: The Over compensation of American Executives. New York: W.W. Norton Company.

Dalton, D.R., C. M. Daily, J.L., Johnson and A. E. Ellstrand (1999). "Number of Directors and Financial Performances". Academy of Management Journal, 42(6), 674-686.

Eisenberg, I., Sundgren, S. and Wells, M.T. (1998). "Larger Board Size, Decreasing Firm Value and Increasing Firm Solvency". Journal of Financial Economic, 48, 35-54.

Fama, E.F and M. C. Jensen (1983). "Separation of Ownership and Control". Journal of Law and Economics. 26(2), 301-325.

Fox, J. (1998). “The Great Emerging Markets Rip-Off:: Malaysia Awakens”, Fortune, May 11, downloaded at http://www.pathfinder.com/fortune/1998/980511/gre1.html.

Jensen, M. (1993). "The Modern Industrial Revolution, Exit and the Failure of Internal Control System". Journal of Finance, 48(3) (July), 831-880.

Kumolu, C. (2007). "Group in Search of Corporate Governance". Vanguard, Aug. 1, 60.

Liu, K.C. and W.G. Zhang (1996). Current Accounting Issues in China: An Analytical Approach. Singapore, PRC: Prentice Hall.

Morck, R., A. Shleifer, and R.W. Vishny (1998). "Management Ownership and Market Valuation: An Empirical Analysis", Journal of Financial Economics , 20, 293-315.

Oaikhenan, H.E. and Udegbunam, R.I. (2004). Modern Statistics for Economics and Business, Benin City: Hennas Publishers.

Rask R, D. Chu, and I. Gottschang (1998). "Institutional Change in Transition Economies: The Case of Accounting in China", Comparative Economic Studies, XXXX(4)(Winter), 76-100. 
Rwegasira,K. (2000). "Corporate Governance in Emerging Capital Markets: Whither Africa?"

Empirical Research-Based and Theory Building Journal, 18(3), 258-268.

Sloan, R.G. (2002). "Financial Accounting and Corporate Governance School of Business

Administration", (downloaded from www. ssrn.com).

Sullivan, J.D. (2000). Corporate Governance: Transparency between Government and Business, Paper

Presented to Mediterranean Development Forum 3, World Bank Meeting, Cairo, Egypt, March,7.

The Central Bank of Nigeria Code of Corporate Governance, 2006.

Wikipedia Online Encyclopedia 2006.

Yermack, D. (1996) "Higher Market Valuation of Companies with a Small Board of Directors", Journal of Financial Economics, 40,185-211.

\section{APPENDIX 1: Data for Discretionary Accruals Estimation Obtained from each Company's Financial Report}

\begin{tabular}{|c|c|c|c|c|c|c|}
\hline $\mathbf{S} / \mathbf{N}$ & COMPANY & TACC & 1/TA t-1 $_{1}$ & (REV-REC & PPE & ROAM $_{t-1}$ \\
\hline 1 & CAP Plc & 0.0931 & $10-^{7} \times 8.04$ & -0.0163 & 0.1296 & 0.1183 \\
\hline 2 & Berger Paints Nig. Plc & -0.4091 & $10-^{7} \times 6.85$ & 0.0159 & 0.8759 & 0.1419 \\
\hline 3 & DN Meyer Plc & -0.3366 & $10-^{7} \times 9.21$ & -0.1583 & 0.2315 & 0.1189 \\
\hline 4 & $\begin{array}{l}\text { West African Portland Cement } \\
\text { Plc }\end{array}$ & -0.0825 & $10-^{8} \times 2.60$ & 0.1176 & 0.7520 & 0.0838 \\
\hline 5 & $\begin{array}{l}\text { Cement Company of Northern } \\
\text { Nig Plc }\end{array}$ & -0.1329 & $10-^{7} \times 1.86$ & 0.0485 & 0.3985 & 0.2214 \\
\hline 6 & Ashakacem Plc & 0.1863 & $10-^{8} \times 7.60$ & 0.1945 & 0.1889 & 0.3699 \\
\hline 7 & Nigerian Bottling Co. Plc & -0.0719 & $10-^{8} \times 2.90$ & 0.2190 & 0.6592 & 0.997 \\
\hline 8 & Nestle Nig. Plc & -0.2599 & $10-^{8} \times 7.50$ & 0.4610 & 0.4379 & 0.4553 \\
\hline 9 & Nigerian Breweries Plc & -0.2627 & $10-^{8} \times 1.20$ & 0.0798 & 0.6282 & 0.1748 \\
\hline 10 & Guinness Nig Plc & -0.1830 & $10-^{8} \times 2.00$ & 0.0265 & 0.5705 & 0.2462 \\
\hline 11 & Dunlop Nig. Plc & -0.2065 & $10-^{7} \times 1.40$ & 0.0359 & 0.6665 & -0.0365 \\
\hline 12 & R.T. Britcoe (Nig). Plc & -0.0247 & $10-^{7} \times 3.59$ & 0.8531 & 0.1416 & 0.1137 \\
\hline 13 & May \& Baker (Nig) Plc & 0.1161 & $10-^{7} \times 7.45$ & 0.1215 & 0.2913 & 0.1583 \\
\hline 14 & Ekocorp Plc & -0.2867 & $10-^{6} \times 1.614$ & 0.0140 & 0.9024 & 0.1430 \\
\hline 15 & Beta Glass Plc & -0.2135 & $10-^{7} \times 1.15$ & -0.1162 & 0.6328 & 0.0626 \\
\hline 16 & Vitafoam Nig. Plc & 0.0262 & $10-^{7} \times 4.85$ & -0.1214 & 0.2432 & 0.2097 \\
\hline 17 & First Aluminum Nig. Plc & -0.0848 & $10-^{7} \times 2.63$ & 0.3780 & 0.4381 & 0.1312 \\
\hline 18 & A.G. Leventis (Nig). Plc & -0.1789 & $10-^{7} \times 1.58$ & 0.1729 & 0.4301 & 0.0516 \\
\hline 19 & UAC Nig. Plc & -0.0581 & $10-^{8} \times 5.6$ & -0.0435 & 0.5598 & 0.1299 \\
\hline 20 & Okomu Oil Palm Co. Plc & -0.0205 & $10-^{7} \times 1.80$ & 0.0521 & 0.8075 & 0.1613 \\
\hline
\end{tabular}




\section{APPENDIX 2: Research and Control Variables Data Obtained from each Company's Financial Reports}

\begin{tabular}{|c|c|c|c|c|c|c|c|c|c|c|}
\hline $\mathbf{S} / \mathbf{N}$ & COMPANY & CEO & PNED & $\begin{array}{l}\text { AUDCO } \\
\text { M }\end{array}$ & INST & SIZE & ROAM & LEV & LOSS & AUDR \\
\hline 1 & CAP Plc & 1.0000 & 0.6000 & 1.0000 & 0.5018 & 6.1834 & 0.2223 & 0.5231 & 0.0000 & 1.0000 \\
\hline 2 & $\begin{array}{l}\text { Berger Paints } \\
\text { Nig. Plc }\end{array}$ & 1.0000 & 0.9000 & 1.0000 & 0.1126 & 6.2770 & 0.0397 & 0.5896 & 1.0000 & 0.0000 \\
\hline 3 & DN Meyer Plc & 1.0000 & 0.625 & 1.0000 & 0.6070 & 6.1364 & 0.09727 & 0.8944 & 1.0000 & 1.0000 \\
\hline 4 & $\begin{array}{l}\text { West African } \\
\text { Portland } \\
\text { Cement Plc }\end{array}$ & 1.0000 & 0.6923 & 1.0000 & 0.7177 & 7.4227 & 0.1491 & 0.6574 & 0.0000 & 1.0000 \\
\hline 5 & $\begin{array}{l}\text { Cement } \\
\text { Company of } \\
\text { Northern Nig } \\
\text { Plc }\end{array}$ & 1.0000 & 0.8889 & 1.0000 & 0.8028 & 6.7720 & 0.1122 & 0.7458 & 0.0000 & 1.0000 \\
\hline 6 & $\begin{array}{l}\text { Ashakacem } \\
\mathrm{Plc}\end{array}$ & 1.0000 & 0.8182 & 1.0000 & 0.5016 & 7.1991 & 0.3768 & 0.5241 & 0.0000 & 1.0000 \\
\hline 7 & $\begin{array}{l}\text { Nigerian } \\
\text { Bottling Co. } \\
\text { Plc }\end{array}$ & 1.0000 & 0.8889 & 1.0000 & 0.6621 & 7.7438 & 0.0815 & 0.6017 & 0.0000 & 1.0000 \\
\hline 8 & $\begin{array}{l}\text { Nestle Nig. } \\
\text { Plc }\end{array}$ & 1.0000 & 0.625 & 1.0000 & 0.6230 & 7.5358 & 0.4686 & 0.8961 & 0.0000 & - \\
\hline 9 & $\begin{array}{l}\text { Nigerian } \\
\text { Breweries Plc }\end{array}$ & 1.0000 & - & 1.0000 & 0.5410 & 7.9044 & 0.2102 & 0.6099 & 0.0000 & 1.0000 \\
\hline 10 & $\begin{array}{l}\text { Guinness Nig } \\
\text { Plc }\end{array}$ & 1.0000 & - & 1.0000 & 0.5380 & 7.9044 & 0.1623 & 0.6352 & 0.0000 & 1.0000 \\
\hline 11 & $\begin{array}{l}\text { Dunlop Nig. } \\
\text { Plc }\end{array}$ & 1.0000 & 0.7500 & 1.0000 & 0.3619 & 7.6724 & 0.0049 & 0.7092 & 1.0000 & 1.0000 \\
\hline 12 & $\begin{array}{l}\text { R.T. Britcoe } \\
\text { (Nig). Plc }\end{array}$ & 1.0000 & 0.5556 & 1.0000 & 0.4968 & 6.7022 & 0.1130 & 0.4197 & 0.0000 & 1.0000 \\
\hline 13 & $\begin{array}{l}\text { May \& Baker } \\
\text { (Nig) Plc }\end{array}$ & 1.0000 & - & 1.0000 & - & 6.8880 & 0.1283 & 0.6137 & 0.0000 & 1.0000 \\
\hline 14 & Ekocorp Plc & 1.0000 & - & 1.0000 & 0.1920 & 6.3004 & 0.1402 & 0.4834 & 0.0000 & 1.0000 \\
\hline 15 & Beta Glass Plc & 1.0000 & 0.9091 & 1.0000 & 0.7667 & 5.6262 & 0.0488 & 0.4264 & 0.0000 & 1.0000 \\
\hline 16 & $\begin{array}{l}\text { Vitafoam Nig. } \\
\text { Plc }\end{array}$ & 1.0000 & 0.5714 & 1.0000 & 0.3120 & 6.6833 & 0.1240 & 0.5949 & 0.0000 & 1.0000 \\
\hline 17 & $\begin{array}{l}\text { First } \\
\text { Aluminum } \\
\text { Nig. Plc }\end{array}$ & 1.0000 & 0.5556 & 1.0000 & 0.8200 & 6.5472 & 0.1378 & 0.6653 & 0.0000 & 1.0000 \\
\hline 18 & $\begin{array}{l}\text { A.G. Leventis } \\
\text { (Nig). Plc }\end{array}$ & 1.0000 & 0.7778 & 1.0000 & 0.8844 & 6.8473 & 0.0906 & 0.3486 & 0.0000 & 1.0000 \\
\hline 19 & UAC Nig. Plc & 1.0000 & 0.7000 & 1.0000 & - & 7.2300 & 0.1349 & 0.3630 & 0.0000 & 1.0000 \\
\hline 20 & $\begin{array}{l}\text { Okomu Oil } \\
\text { Palm Co. Plc }\end{array}$ & 1.0000 & 0.9000 & 1.0000 & 0.6634 & 6.3919 & 0.1104 & 0.3440 & 0.0000 & 1.0000 \\
\hline
\end{tabular}

